\title{
Bounded Tourism: Immigrant Politics, Consumption, and Traditions at Plaza Mexico
}

Clara Irázabal

School of Public Policy, Planning and Development, University of Southern California, USA

Macarena Gómez-BarrisSociology and American Studies and Ethnicity, University of Southern California, USA

Abstract: Conceived and owned by Korean investors, the shopping mall Plaza Mexico in Southern California embodies a unique case of invention and commodification of traditions for locally-bound immigrants and US citizens of Mexican descent, showing the force of the contemporary processes of deterritorialisation and reterritorilisation of identities and the recreations of imagined conceptions of homeland. The Plaza is a unique architectural recreation of Mexican regional and national icons that make its patrons feel 'as if you were in Mexico'. Plaza Mexico produces a space of diasporic, bounded tourism, whereby venture capitalists opportunistically reinvent tradition within a structural context of constrained immigrant mobility. While most of the contemporary theory of tourism, travel and place emphasise the erosion of national boundaries and the fuidity of territories, the case of Plaza Mexico brings us to appreciate this phenomenon and its opposite as well the strengthening of national borders and their impact on the (in)mobility of millions of individuals.

Keywords: tourism, place, immigrant politics, Los Angeles, Plaza Mexico, diaspora

A place you leave is a place that lives forever (tagline of The Lost City, directed by Andy Garcia, 2005)

Que lejos estoy del suelo How far I am from the land donde he nacido, where I was born, inmensa nostalgia invade immense nostalgia invades mi pensamiento; my thoughts; y al verme tan solo $\mathrm{y}$ triste and finding myself so lonely and sad cual hoja al viento, as a leaf in the wind, quisiera llorar, I'd like to cry, quisiera morir de sentimiento. I'd like to die of sorrow. 
Oh tierra del sol, Oh land of sunshine, suspiro por verte I sight for seeing you ahora que lejos now that far away yo vivo sin luz, sin amor; I live without light, without love; y al verme tan solo y triste . . . and finding myself so lonely and sad . . . José López Alavéz’s (1889-1974) ‘Canción Mixteca’1

Plaza Mexico is a place of fantasy, of reinventing tradition and of consumption; it is a themed shopping centre in metropolitan Los Angeles. Though many shopping malls serve some functions of public space, Plaza Mexico reproduces the plaza experience of Latin America in the heart of southeast Los Angeles - in Lynwood, California. Tellingly, its architecture is modelled after 'traditional' Mexican towns and includes a pastiche collection of Mexican cultural symbols of different eras. As such, the mall's architecture, store offerings and event programming have created a successful formula to attract a large number of mostly Mexican and Mexican American clientele, and increasingly a broader Latina/o clientele. Like the public spaces of Latin American cities, the draw of Plaza Mexico, especially on weekends, is its cultural events, ethnic and religious commodities (food, Mexican memorabilia, folk and first communion dresses, Catholic icons and so on), and a place to hang around in an environment that 'feels like home' (mall slogan). It is, as Zukin discusses for other contemporary spaces, 'a dreamscape of visual consumption’ (1991: 221). Conceived and owned by Korean investors, Plaza Mexico embodies a unique case of invention and commodification of traditions for locally-bound immigrants and US citizens of Mexican descent, showing the force of the contemporary processes of deterritorialisation and reterritorilisation of identities and the recreations of imagined conceptions of homeland. In this paper, we identify how Plaza Mexico produces a space of bounded, diasporic tourism in Southern California through nostalgia, belonging and the culling of national and regional identification.

What is unique about this public space is the degree to which it is conceived and indeed capitalises upon consumer identification with homeland within a structural context where its mostly immigrant clientele has little capacity to make return trips to Mexico. Indeed, in the aftermath of a US immigrant backlash with increasingly stringent state immigration policies and anti-immigrant political climate, Plaza Mexico produces a physical and cultural space that 
imitates 'the best' of Mexico without requiring the increasingly impossible journey of return. Historically, one of the classic defining features of immigrant life is that it is horizontally mobile, following labour opportunities even while immigrants are often caste within niche labour markets. 2 While migrant populations continue to certainly be on the move, as the expanding Mid-Western and New York migrant communities show us, both because of socioeconomic limitations, and due to the increased US-Mexico border fortification, surveillance, deportation sweeps and political climate that defines immigrants as 'aliens', the prospect of mobility across the border has decidedly declined. The recent commercial success of Plaza Mexico must be located within these structural shifts.

How do structural shifts in immigrant policies facilitate capitalist enterprises that market nostalgia and local tourism within transnational contexts? Our objective in this paper is to insert the case study of Plaza Mexico as a new form of venture capitalism that targets specific ethnic market niches - mostly composed of diasporic subjects trapped in place - while also seizing upon shifts in immigrant politics in ways that both confirm and contest existing literature on tourism, immigration, identity and place. Our research findings, observation and analysis are based on six months of qualitative research, multiple trips to Plaza Mexico, our first-hand observations and the work of an excellent group of graduate research assistants. Our approach to the field portion of our research is qualitative in that we used both long surveys, shorter surveys, scheduled interviews and ethnography at key cultural, political and religious gatherings to acquire information about how the clientele at Plaza Mexico used and viewed the space and architecture at the Plaza. We also interviewed persons in key management positions to address the history, architectural plans, multiple uses and future plans for the site. Key to our understanding of the plaza, as subsequent sections show, is how the urban planning, architectural design and events at the Plaza open up forms of consumptive citizenship that both reproduce structural inequalities in the city, and the nation more broadly, and provide practical and embodied responses to those very inequalities by the choice to tour the Plaza.

Plaza Mexico, USA 
The Plaza is a unique architectural recreation of Mexican regional and national icons that makes its patrons feel 'as if you were in Mexico'. Its façades and architectural motifs such as plazas, kiosks, fountains and monuments are characteristic of several Mexican cities; among them, the Angel of Independence of Mexico City and a kiosk of the Zocalo of San Miguel de Allende, Guanajuato, which show up as replicas in Plaza Mexico. The Plaza's paving is made of stone (adoquín) and its benches of crafted iron, 'just like the ones found in the provinces of Mexico', boasted one of its planners. One of the most interesting sites of reinvention of tradition is the reproduction of the façade of the Palace of Jalisco. For its construction, original materials were brought from Mexico, such as stone from Zacatecas and talavera from Puebla. The physical arrangement of the mall emulating open streets and plazas has enhanced its atmosphere as a 'traditional' Mexican town where people stroll at ease or participate in cultural or recreational events in a manner as in Mexico. In this way, Plaza Mexico is part of a global trend towards increasing thematisation of spaces of entertainment and consumption (Gottdiener, 2001; Irazábal, 2007) in which visual technologies such as sculptures, exhibits and shows induce the tourists' gaze (Urry, 2002).

Easily accessible by transit and strategically located off the I-710 and I-105 and near the I-110 freeways, Plaza Mexico is easily reached from the majority-Latino/a cities in east and south Los Angeles. The mall is located in the midst of a Mexican majority community. Lynwood's population was of 69,845 inhabitants in 2000 , of which 57,503 or $82.3 \%$ were Latina/os, 46,491 or $66.6 \%$ Mexicans and 30,475 or $43.6 \%$ immigrants (Truax, 2005). Plaza Mexico thus functions as a social gathering space in a neighbourhood where there are not many other options of 'public' open space available to its residents. The visitors of Plaza Mexico enjoy the space precisely because the mall allows for the possibility of self-perception as individuals who appreciate Mexican 'traditions' and as agents that reproduce them. In a neighbourhood that otherwise has been economically deprived for years and that shows signs of decay in its built environment, Plaza Mexico is a source of community pride and enjoyment, and provides a gathering space with multiple potentials. 
There is a vast literature that analyses immigrant enclaves, which mostly emphasises economic, social mobility, labour and entrepreneurial standpoints (see e.g. Light \& Gold, 2000; Waldinger, 1986; Zhou, 1992).Abrahamson's seminal work on urban enclaves (1996, 2005), however, inspired a renovated focus on identity and place, a spatial turn to what this work adds. We expand this focus on identity and place to show how Plaza Mexico redefines urban ethnic centres or ethnic commercial strips, which are common entrepreneurial centres and gathering nexuses in all major US cities. Historically, ethnic enclaves have helped develop cultural, community and commercial facilities and programmes that serve the specific needs and desires of their population and cater to other appreciative urbanites.3 These facilities, however, usually evolve in a piecemeal fashion, have different owners, and form part of the existing urban grid of city streets, organised in clusters or linear fashion along main streets or intersections. Plaza Mexico does not follow these characteristics. Instead, it has evolved in large phases, each of which is composed of a dozen or more stores built simultaneously. Under single ownership and rupturing with the existing urban grid in Lynwood, Plaza Mexico is instead organised as a detached, inward-oriented island surrounded by parking space. The typology of the Plaza thus constitutes a corporate cooptation of the traditional ethnic strip model, which has been recreated within a private shopping centre.

Plaza Mexico functions as a 'miniature park' of sorts in which an assortment of Mexican façade architecture, open space landscaping, patriotic symbols and religious icons create a setting in which an idea of Mexican national authenticity has been repackaged for mall patrons. This effect is stressed by many of the commodities offered in the mall, which are either made in Mexico or made as if in Mexico - from regional ice cream flavours to Mexican folk clothing. In addition, the Plaza hosts a busy calendar of Mexican festivities and cultural events that highlight Mexican folk music, dances and other artistic expressions. Evidently, there is a process of selection of what constitutes deserving elements of Mexican culture to represent the nation in the Plaza. Tellingly, the mall's Korean owners hired two Mexican public relations coordinators, both of whom are highly knowledgeable and passionate about Mexican national culture, to lead the process of selecting the icons, events and personalities that 
are portrayed. Even the selection of construction materials and the construction process itself has been carefully monitored to guarantee quality and Mexican 'authenticity'.

Most emblematic of the attempt at architectural authenticity, is the scaled-down reproduction of Mexico City's Angel of Independence, one of the primordial symbols of the Mexican nation, which currently marks the major entrance to Plaza Mexico. Mexicans in Mexico and abroad have all seen the Angel, if not in person at least through media. Plaza Mexico’s Angel has been crafted with the same materials and design plans as the original, and it is said to be smaller only because of earthquake safety concerns (Aguilar, 2006). Even though the Angel is not located on a central thoroughfare in the city, unlike the original in Mexico City, and is separated from the city's grid by a parking lot, it is an important statement and symbol of Plaza Mexico's importance in the community. The replica of the Angel has produced some interesting responses. For instance, in spite of being a smaller version than the original, an elderly Mexican woman reportedly cried at the sight of the replica of the Angel, believing the original had indeed been transported to Lynwood from Mexico City. In addition, the Angel has become an important site of congregation for recent political rallies, replicating its traditional role in Mexico City. During the March and April 2006 student walkouts, and larger protests in Los Angeles to US congressional immigration reform proposals, groups gathered at the Angel before marches to Los Angeles City Hall. Significantly, the Plaza owners and managers did not resort to calling the police, but were rather mesmerised at the symbolic power of their Angel's reproduction. As Cristina Aguilar, the Program Manager told us in an interview with her, 'Lynwood police eventually intervened only to have some students who had climbed the Angel (as if in Mexico) come down from it for safety reasons, but we did not request them to expel the students from the private property of the mall'.

One anecdote especially reveals the social context of the memorial's original and its copy. It has become a tradition in Mexico City that when Mexican sport teams win international competitions, people gather and walk around the Angel of Independence to celebrate the victory. Spontaneously, during the football World Cup of 2006, people gathered in Plaza Mexico to watch the games, congregating 
around the Angel of Independence after a victory or tie. Spanish TV channels in Los Angeles showed the parallels between the celebrations around the two Angels of Independence - in Mexico City and in Plaza Mexico, Lynwood. These images also evidenced the ultimate irony: since the Angel of Independence in Mexico City was undergoing renovation, it was totally hidden under a black cover. In contrast, the Angel of Independence in Plaza Mexico, the copy of the original, shined brightly on local television.

The Angel of Independence is but one of the replicas, imitations, incorporations and reworkings of Mexican national architecture and symbolism at the mall. In general, there is a selective editing of traditions and values that are deemed worth of portraying at the Plaza. The Plaza's managerial team selects which traditions and symbols are portrayed, and these are based on historical (preHispanic, colonial and folkloric), Catholic, familial, patriotic, heterosexual and patriarchal values. These symbols reify the myths of both a shared Mexican national identity and a homogeneous Mexican community in the Southern California region. Such forms of selection of architectural elements give claim to a particular vision of the past in the contemporary moment, where nostalgia is reified through cultural memory (Gómez-Barris, 2007), even while such selections may appear 'natural'.

As we learned from Plaza Mexico representatives, the pastiche of cultural icons in Plaza Mexico will continue alongside the mall's expansion to incorporate an ever wider arrangement of 'traditional' architectural elements. For instance, a pyramid is envisioned for one of the mall's planned expansions. A Plaza representative we interviewed offered this matter-of-fact explanation: 'It [the Plaza] is not Mexican if it does not have a pyramid'. However, the Plaza's multiple symbols focus exclusively on the past - the pre-Columbian, the colonial and the early Republican periods - and there are no plans to represent Mexico in the era of modernity and economic globalisation. This purposeful omission effectively plays on dual emotions of nostalgia and the myth of Mexican purity that has not been contaminated by the present economic and political processes. Besides, in order to become an effective display of Mexico, the Plaza instrumentally focuses on symbols that hark to its European 
and Indigenous hybrid identity, the hegemonic and nationalist image of an authentic Mexican national culture.

The Tourism of Staying Put

We follow Oakes who sustains that 'the tourist-subject needs to be recast as a place-based experience of encounter, rather than a displaced and authentic-seeking traveler' (2005: 40). In Los Angeles, tourist centres like Olvera Street have historically functioned as spaces of fantasy that stood in contrast to the daily experiences of Mexicans in Los Angeles, especially during the 1930s Depression era (Estrada, 1999: 122). Estrada argues that Olvera Street was 'an imagined Mexican landscape' not unlike the tourist areas of border cities in Mexico (Estrada, 1999: 107). Unlike Olvera Street, a Mexican-themed tourist destination in the birthplace of the city for mostly Anglos, but also Asian, African American and Latino patrons, Plaza Mexico is a notably 'brown' and Mexican retail and cultural space. In the heart of the global city, the Plaza activates a distinct phenomenon of diasporic, bounded tourism, where the Plaza is an available surrogate for a Mexican homeland. Plaza Mexico's role activates immigrant, bounded tourists/tourism, as many Plaza visitors do not have the legal or economic resources to travel to Mexico - even if desired. In effect, most Plaza visitors are of low or middle-low income and their families are larger than the average for the state of California or the US,4 and those without legal US permanent residency or citizenship rights face exceedingly harsh border conditions. For these reasons and more, travelling to Mexico constitutes an onerous proposition for large segments of the Los Angeles immigrant population. Plaza Mexico cleverly targets this expanding, yet previously unrecognised, niche for tourist and consumption: forcefully bounded-in-place individuals with a desire for ethnic consumption and leisure, great nostalgia for an idealised homeland they cannot easily return to, and some time and money to spare.

Subject positions and subject formations are processes in flux that are also constituted and transformed through what Lew and Cartier call 'touristed landscapes', that is, leisure-oriented places 'that offer promise of escape from daily life - for a week, a day, or even an hour' (2005: 302). As we know from the work of Hobsbawn (1983), 
AlSayyad (2001), and others, invention and commodification of traditions is a sign of our times. The dual approach of invention and commodification are strategies that have been used by cities to reinvent their pasts, build up a 'uniqueness' of place, portray a competitive and coherent city image in a global world, and boost up their economies and tourist industry (Cartier \& Lew, 2005; Fainstein \& Judd, 1999a; Irazábal, 2004, 2005). In fact, these are common economic development strategies for large and global cities, but are increasingly becoming ever more popular among smaller ones. Perhaps the most conspicuous example of heritage manufacturing occurs in the new generation of hotels-casinos in Las Vegas, which simulate cities (e.g. New York-New York, Paris Las Vegas, The Venetian, and so on). The profit driven aims of these productions tap into the affective needs of the contemporary post-modern subject, who feels the urge to crystallise idealised notions of urban time and 'placeness' to confront the ambiguities and fragmentations of temporality and space in the global urbanised world (Irazábal, 2007). For diasporic and immigrant populations, these ambiguities and fragmentations become more acute, sometimes menacingly so, when their permanence in the host nation is under threat. Under these conditions, time- and place-based nostalgias can be more eagerly engaged by diasporic subjects, a context that in part explains the popularity and draw of Plaza Mexico for Mexican immigrants.

Mexican immigrants and Mexican Americans in the US have undergone different processes of deterritorialisation and reterritorilisation of their social identities, which have historically worked to shift their perceptions of homeland. These historical and contemporary dynamics have occurred through spatial, subjective, and economic processes of displacement from/within the US, and migration from the so-called Third World to the First (Irazábal \& Farhat, 2008). An important violent marker and rupture in social identities happened in the 19th century, during the Mexican American war (1846-1848), which led to the signing of the Treaty of Guadalupe Hidalgo in 1848 in which present day Arizona, California, New Mexico and parts of Colorado, Nevada and Utah, or Mexico's northern third, was annexed by the US.5 In the 20th century, Mexicans and Mexican-Americans were subjected to several periods of forced repatriation as a result of racial discrimination following the Great Depression of 1930s and other 
historical processes (Deverell, 2004; Sanchez, 1993). In 1930s Los Angeles, this meant relocating Mexican residents to the east side of the city (Estrada, 1999; Romo, 1983). In the 21st century, we are witnessing a new rise of anti-immigration policies and practices that cause the forced deportation of many undocumented Mexican immigrants, including parents of American children. These debates in the sphere of politics and media have been fueled, among others, by renowned conservative scholar, Samuel Huntington (2004), who claims that, in general, Latina/os are not willing to assimilate to US mainstream culture (conceived as Anglo-Protestant) and thus threaten the nation's unity. Within this political climate, Mexico alongside the Middle East, Africa and much of the 'Third World' is constructed as reified 'Other', a condition compounded by its proximity to the US and the large Mexican presence within US borders.

Mexican migration to the US, both documented and undocumented, is a long-dated phenomenon, one that has peaked in the last 10 years. The Center for Immigration Studies has noted that between 1990 and 2000, their number doubled - from 4.2 million to 9.2 million, or $30 \%$ of the entire foreign-born population in the country. Further, within this underestimate, the population of unauthorised Mexican immigrants grew by more than $100 \%$ - from 2 million to 4.8 million, making up $69 \%$ of all unauthorised immigrants in the US. In a statement that helped heighten nativist discourses about an immigrant invasion, Senator John McCain (2004) stated in February 2004 that almost four million 'undocumented aliens' crossed the US borders in 2002. To give a sense of the proportion of the national challenge this posed, the senator gave the following fact, which fuels the construction of immigrants as criminals: 'If, in estimate, one out of four were apprehended, that would mean in the year 2002, three million undocumented entered the US and evaded apprehension.'6

Within a political and media climate where discourses of alienhood7 (Marciniak, 2006), radical alterity and invasion are contentious, but nonetheless widely available, the threat of deportation hangs very heavily in the minds of undocumented immigrants in the United States and greatly conditions many aspects of their lives, including opportunities for housing, education, labour, driving privileges and citizen rights. Also, as is true for all immigrants, for Mexican 
immigrants there are usually long periods of adjustment, nostalgia and need to reterritorialise a sense of Mexicanness, perhaps over a period of multiple generations, so that it becomes a defining characteristic of identification on this side of the border. Plaza Mexico responds to these increased external pressures by providing a place of solace, gathering, and the reterritorialisation of individual and collective identities of its mostly Mexican immigrant clientele.

Plaza Mexico both reasserts and defies conventional dynamics of tourism. On the one hand, the mall reproduces conventional dynamics of local tourism, as the Plaza attracts local and regional visitors who want to experience a taste of 'real' Mexico within California. It also rekindles the attraction of Mexico as a destination for visitors with the legal and economic resources to travel abroad. On the other hand, the Plaza plays an expanding role as a representation of Mexico and 'proper' Mexicanness in a transnational context. This happens in several ways. For example, Casa Puebla and Casa Durango, hometown associations that unite and serve people from those particular regions of Mexico now residing in the United States, have established locales in Plaza Mexico. These casas serve Mexican nationals with legal businesses and economic transactions both in the United States and Mexico, and promote Mexican culture, commerce and tourism. Another instance of the connection between commerce, immigration and government institutions was instantiated by the Mexican Consulate opening a temporal office in the Plaza to get its nationals registered for Mexican elections and to deliver special identification cards (cartas consulares) that Mexicans can use in the United States for certain legal purposes. Also, personalities from Mexico - for example, mayors, governors and actors/actresses - frequently make official appearances in the Plaza while visiting Southern California. These visits are usually linked to larger events in the Plaza, such as the inauguration of a statue (which is typically donated by the respective hometown association), business meetings or cultural shows. Plaza Mexico's popularity has also grown as a spot for Latina/o radio and TV broadcastings, and is often used as setting for Mexican-related TV interviews, shows and news.

According to Fainstein and Judd, a 'converted city' is 'a type of tourist city in which specialised tourist bubbles are carved out of 
areas that otherwise would be hostile to or inconvenience for tourists' (1999a: 266). The construction of tourist enclaves is a common urban strategy used for neighbourhood revitalisation and the promotion of economic development. Plaza Mexico expands those opportunities opening a new tourist and commercial market niche, because it constitutes a tourist enclave that primarily serves an emplaced diasporic population. Furthermore, it is a tourist enclave for a low income ethnic class in a global city. Thus, not only does it capture an ethnic segment of the market previously under targeted, but also a socio economic one. As it is common in other converted cities, piecemeal development in Lynwood is stalled, and private development enterprise is taking over. As a matter of fact, Plaza Mexico is considering several phases of expansion, including new shopping and recreational areas and a parking structure.

Catering to people in lower income brackets in the region of Los Angeles, Plaza Mexico does away with commonly held assumptions about tourism. 'Obviously', claim Fainstein and Judd, 'tourism is not a recreation of the poor' (1999a: 267). Disproving this axiom, Plaza Mexico is successfully appropriating a strategy that has served corporate giants such as Walmart, and thus may constitute a new frontier for the development of the corporate tourist industry. In effect, if, as Fainstein and Judd state, 'the main spatial effect of urban tourism is to produce spaces that are prettified, that do not feature people involved in manual labour, ... that exclude visible evidence of poverty, and that give people opportunities for entertainment' (1999a: 269), then who would be more in need of and would desire more for all that than the ones who live their everyday lives exposed to the opposite conditions? Thus, for the ethnic urban poor, the escapist dimension of tourism becomes greatly realised in Plaza Mexico. Escape from difficult labour, housing, citizenship and poverty conditions is certainly one significant dimension of the tourism that is realised in Plaza Mexico, though we do not want to overstate 'escapism' since leisure is an important dimension of living for all people regardless of structural constraints. In any event, this segmentation and specialisation of the tourist industry, a cultural business par excellence, concords with the role of culture in global capitalism, as perceived by several authors: 'since capitalism thrives on the construction of difference, the present era of economic universalism will only lead to further forms of division, in which 
culture will become the globally authoritative paradigm for explaining difference and locating the "other" (AlSayyad; 2001: 8; King, 1991; see also Robertson, 1991). Plaza Mexico has been constituted as a 'cultural territory' (Cohen, 1985), whereby the local community has developed an emotional connectedness with the Plaza as a spatial expression of Mexicanness. According to Upton, this is a manifestation of a new phase of modernity and capitalism:

Capitalism no longer seeks raw materials and markets for its industrial goods alone, but cultural raw materials that can be transformed into hard cash through the conservation, restoration, and outright fabrication of indigenous landscapes and traditional cultural practices for the amusement of metropolitan consumers. (Upton, 2001: 298)

While most of the contemporary theory of tourism, travel and place emphasise the erosion of national boundaries and the fluidity of territories, the case of Plaza Mexico brings us to appreciate this phenomenon and its opposite as well - the strengthening of national borders and their impact on the (in)mobility of millions of individuals. Yet, material mobility may be severely diminished for the undocumented immigrants trapped in place in the United States, but social and imaginative mobility are not. These other dimensions of mobility allow for Plaza Mexico to be a profitable commercial enterprise and a place where many visitors can imaginatively reinhabit the homeland.

\section{Fixing Tourists In-Place and Dis-Placing Tourist Sites}

The tourist industry is mostly geared towards consumers travelling far away from home. As Fainstein and Judd describe, '[q]uintessentially, the tourist is a consumer away from home' (1999: 14). Cartier and Lew (2005), however, acknowledge that a person can become a tourist visiting his or her own local venues, as long as they partake in place/community exploration, entertainment and consumption. In the case of Plaza Mexico, there is yet another type of tourist - one who is permanently away from the homeland, longs to visit it but is prevented from doing so and sees connection to the Mexican nation as a quintessential feature of one's own identity (and what gets actualised at Plaza Mexico). Thus, it is tourism catered to a trapped diaspora, which bring to its hosted land the longed for, 'authentic' traditions and commodities of the homeland for their 
consumption away from home. This third kind of tourism that we describe, in fact, upsets the conventional roles assigned to tourists and places, whereby tourists are the ones to travel to 'fixed' locales. In this case, tourists are fixed in their host locale and the place they long to visit is virtually brought to them through simulations of architecture and media, and the reproduction of commodities - the fixation of tourists in-place and the dis-placement of tourist sites. It is a special type of 'diasporic tourism': neither is it constituted by tourists coming from afar to visit a diaspora in a foreign region or country (such as New York tourists visiting 'Little Italy' or any such ethnic enclaves populated by diasporas in the city), nor by tourists from diasporas visiting their homelands (such as Chinese Americans visiting China). In this new twist of 'diasporic tourism,' neither the diasporic subjects of Mexican Lynwood inhabit a place that has become a tourist site (i.e. they are not recognised as a worthy of visit ethnic enclave), nor they have the choice - because of legal or economic constrains - of visiting the homeland. Trapped in this liminal space, neither the performers of tourist gazes abroad nor the objects of tourist gazes at home, they have been reinvented by the tourist industry as a total package in situs: as both the performers and the objects of tourist gazes at their diasporic home - a reflexive tourism. The Plaza visitor becomes both a subject and an object of the exhibition of Mexicanness. Her or his role as an object becomes paramount at special events, through the performance of Mexican artistic traditions. The Plaza visitor is then a performer of 'engazement', 'the process through which the gaze transform the material reality of the built environment into a cultural imaginary' (AlSayyad, 2001: 4).

Perhaps the most eloquent and spectacular example of this fixation of tourists in-place and the dis-placement of tourist sites in Plaza Mexico occurs during Virgin of Guadalupe celebrations on 11th and 12th December. The events are full of 'as-if-in-Mexico' occurrences, from the Catholic masses to the altars, the offering of candles and flowers, the Aztec dancers, the theatrical performance of the Virgin's apparitions, the singing of Mañanitas, the blessing of sacred images, the dressing of small children as indigenous Saint Juan Diegos and campesinas, etc. The fact that these manifestations happen in a private shopping centre rather than in a church space is a phenomenon of its own, discussed elsewhere (Gómez-Barris \& 
Irazábal, 2006b). Although all those manifestations bring the experience of the place of the Virgin's apparition in Mexico to the locally-bound Mexican diaspora in Southern California, the circumstance that makes the ultimate dis/re-association of tourists and tourist site are the souvenirs from the Tepeyac Mount - the name of the hill in Mexico City where the Virgin appeared - on sale during Virgin of Guadalupe celebrations in Plaza Mexico. In effect, the Plaza visitor can find many typical souvenirs, from keychains to T-shirts to Virgin reproductions that state, 'Recuerdo de mi visita al Monte del Tepeyac' (souvenir of my visit to the Tepeyac Mount). These souvenirs effectively convey a message that being at Plaza Mexico for the Virgin of Guadalupe celebrations is virtually the same - culturally and religiously - as being in the Tepeyac Mount. You can even have a souvenir that proves it.

Aside from its particularities, the experience of many Mexicans in US diaspora has similarities with that of other diasporic groups. Increased migration and dislocations around the world have given rise to what has been called 'nostalgia tourism to former homelands' (Veijola, 2006: 78; author's emphasis). Lew and Wong, for instance, analyse the overseas Chinese's experiences of 'existential tourism' in China, whereby diasporic Chinese go soul-searching in China. Overseas Chinese, they identify, 'are often more bound to the idea of China than those who never left' (2005: 288; author's emphasis). Similarly in this case, many Mexicans in the US are often more bound to the idea of Mexico than those who never left. However, they often do not have the opportunity to engage in 'existential tourism' - or any other type of tourism, for that matter - in the homeland because of structural constraints brought about by their legal and/or economic status. In cases like these, nostalgia tourism to a recreated homeland in situs can become the next best thing: 'by surrounding ourselves with markers and reproductions we represent to ourselves ... the possibility of authentic experiences in other times and other places' (Culler, 1981: 132; cited in Crang, 2006: 50). Furthermore, Lew and Wong offer a sobering conclusion to their study inspired in Salman Rushdie's Imaginary Homelands (1991: 300): 'we can never go "home" again, no matter how many visits we make, because the homeland and the home village are as much imaginary places as real ones. ... [A]ll identities are impermanent and the only real home is the entire world'. In this context, Plaza 
Mexico’s construction of a Mexican touristed landscape in California enacts a 'diasporic orientalism' - the exotisation of 'other' lands (Mexico) in the transnational arena, primarily enacted not by foreigners, but by Mexicans, who in this case are absent natives in a foreign nation.

\section{Touristed Ethnoscape}

Cartier's notion of touristed landscape allows us to analyse Plaza Mexico as a landscape that is toured, lived in and visited by local residents who 'mov[e] in and out of "being a tourist"' (2005: 3). We expand what she identifies as 'the messiness of tourism as category of activity, experience, and economy' (ibid). In the same vein, the 'new mobility paradigm' expressed by Urry (2006: vii) as a result of the cultural and spatial turn in the social sciences, is useful. It conceives 'places as material, embodied, contingent, networked, and performed' (2006:viii). Accordingly, 'places are economically, politically, and culturally produced through multiple networked mobilities of capital, persons, objects, signs, and information' (2006: ix). Minca and Oakes further conceive of place-making as 'fundamentally infused with travel and all the baggage that gets shipped along the way - difference, strangeness, alienation, nostalgia, homesickness, inspiration, fear, frustration, hopes, and expectations fulfilled and dashed' (2006: 1). In more poetic words, Crang suggests that 'the paradox of experiencing a place is that it depends on other absent places' (2006: 54). All these subtleties and complexities are best captured in the case of Plaza Mexico through the notion of touristed ethnoscape.

There are two dimensions of ethnoscape, a term used to describe ethnic representation of/in the landscape, that are applicable to Plaza Mexico. First, it is revealing to understand the Plaza as an ethnic landscape with multifaceted conditions. Centrally, it refers to the people that live around the mall and the ones that visit it. It also refers to the products and special events that are sold and celebrated there. Second, the more complicated notion of ethnoscape, which we borrow from Appadurai, refers to 'the landscape of persons who constitute the shifting world in which we live: tourists, immigrants, refugees, exiles, guest workers and other moving groups ... [who] appear to affect the politics of and between nations to a hitherto 
unprecedented degree' (Appadurai, 1995).8 Appadurai understands the ethnos as a paradigm of the new global cultural economy. According to Appadurai, it is no longer possible to speak of ethnos as a quality settled in a locality. Appadurai's notion melds accounts of various modes of mobility - tourism, business travel, migration, asylum-seeking, education, job type - with diverse collective imaginations of movement and place that circulate in various media - film, Internet, print and so on. In Appadurai's view, many people experience themselves and perceive others as 'between-places' because of this entwining of collective imaginings and movements. References to elsewhere permeate the everyday production of locality because collective imaginings have taken on a hitherto unregistered momentum. Appadurai's theory describes a complicated and at times even turbulent confluence of mobility and imagined mobility (Appadurai, 1996). This conception of ethnoscape provides thickness to our understanding of the Plaza. Many visitors to Plaza Mexico are immigrants who come to the United States mostly from Mexico and Central America in search of better economic opportunities. These immigrants, once settled in Los Angeles, engage in transnational practices, reinventing through their reenactment of traditions some of the cultural practices and values they held in their original locales. These transnational practices transform both the immigrants' homelands and their new host land in the United States through ethnic identifications and markings. According to Peña (2003a, 2003b: 72), these displaced transnational communities 'are remaking their identities though a process that might be characterized as subaltern "relocalization" and "reinhabitation"'. Of course, the use of media is also a critical component that dramatically expands diverse collective imaginations of movement and place. In the case of the Plaza, the use of Internet, newspapers, television, and radio are instrumental in constructing the sense of community and sense of place that the Plaza enjoys, and helps expand the collective imagination around this ethnoscape.

Through the notion of touristed ethnoscape, we challenge common assumptions of tourism, tourists, and their linkages to culture and the economy. Particularly evocative is Crouch's analysis of tourists' 'flirtations with space', which offers a multi-dimensional approach to the embodied experience of 'doing tourism'. The notion of embodiment folds spatiality, experience, and agency, and allows 
subjects to make personal sense of heritage, culture and landscape (Crouch, 2005: 33). Central to Crouch's analysis is that 'pre-figured meanings' of identities, tourists' desires and places 'may be disrupted by the way people practice tourism and its spaces' (Crouch, 2005: 23). Crouch's liberating notion considers 'the agentive and dynamic role of the tourist' (Crouch, 2005: 27). He further acknowledges a 'self-reflective tourist', one who is 'less duped than aware, less desperately needing identity than using tourism in the negotiation of identity' (Crouch, 2005: 25). In the same vein, Crouch considers space as 'constructed through practice in a tension with context but not pre-figured by context' (Crouch, 2005: 27). This allows new grounds for both the politics of tourism and the micropolitics of the tourist-subject, processes that we see unveiling in Plaza Mexico.

Manufacturing Transnational Traditions

Even while the architecture and decorative features at Plaza Mexico reproduce the colonial and nation-building period as central signifiers of Mexican identity, the place problematises the analyses of tourism as a product of neo-colonialism and imperialism (Crick, 1989). As some scholars have described, tourism in the global era is a manifestation of a neo-Marxist 'pleasure-periphery' (rather than core-periphery) world dependency (Robinson, 2001: 45; Turner \& Ash, 1975). Classically, the main direction of tourism is from the socalled First World to the Third World, where the fantasy of exoticised populations, tropicalised geography and unrestricted leisure and pleasure provides a letting off of steam for the FirstWorld overworked middle-class. There are numerous ideological and material channels of late capitalism that enable this type of world tourism (capital, credit, information and the ideologies of consumption and hedonism), which mainly originate from and are controlled by the First World. However, Third World low-income immigrants located in the First World and exposed to the ideologies of consumption and hedonism, are often times relatively disenfranchised in terms of capital, credit and information, and further disenfranchised in legal status (lacking immigration papers), conditions that prevent many of them from travelling abroad to their own nations. 
Gregory speaks of 'the colonial present' rather than the condition of 'postcoloniality' to show, as he puts it, that 'fatal attractions of colonial nostalgia are inscribed within contemporary cultures of travel' (2001: 113). Plaza Mexico, following Gregory’s analysis, is a space of constructed visibility, a stage in which Mexico is rendered in particular ways for a targeted audience outside Mexico: for those originally from there or for later generations of Mexican-Americans who still have a strong imaginary about and emotional connection to the original homeland. The staging selectively draws from multiplesited geographies and temporalities inside Mexico, and through discourses and practices constructs 'a tensile apparatus of power, knowledge, and geography' (Gregory, 2001: 115). Gregory further suggests that the micro-practices involved in the creation of these spaces are not only top-down, however hegemonic they seem to be, but also bottom-up and multi-directional. What this means for Plaza Mexico is that while capital venturers, Spanish radio and television broadcasts, program directors, planners and architects together produce a unified image of a reterritorialised Mexico in this space, those that patronise and gather there also use the space in ways that reflect their own imaginaries of nation, their own yearnings for homeland and their own needs for individual and collective identification.

In terms of the top-down vision of architecture and planning at Plaza Mexico, it is important to signal its hyperproduced and manufactured quality of tradition. However, Upton and others assert that '[m]anufactured traditions are not inherently pernicious' (AlSayyad, 2001b; Upton, 2001: 299). Actually, 'manufactured' and 'authentic' traditions could attend to national and ethic goals with equal footing (Hobsbawn \& Ranger, 1983; Upton, 2001: 299). Rather than thinking about fixed qualities of sites or cultural practices, Upton further proposes 'to understand heritage, tradition, and modernity as strategic political positions’ (Upton, 2001: 300). This is particularly revealing in his definition of the cross-cultural construction of homeland as elements of history and fantasy stitched together to symbolise the nation (Upton, 2001: 302), a notion that has relevance for the multiple ways in which architecture, landscape design, shops, and products come together in Plaza Mexico to inscribe a particular national Mexican space of purity and fantasy within the heart of Gringolandia. 
In this sense, it is impossible to discuss Plaza Mexico without referencing Disneyland, where history is used to create a dream landscape where all cultural conflicts are resolved and all cultural aspects are reduced to their basic representations (AlSayyad, 2001b: 9). Disneyland, now more than half a century old, has been followed in the Southern California region by several theme parks that exploit Disney's notion of invented streets and invented places (Banerjee, 2001). More recently, the boom of lifestyle centres or entertainmentretail centres in the Southern California region, such as Paseo Pasadena, Hollywood \& Highland, and The Grove have revealed new market opportunities derived from greater segmentations of the regional consumer market that rely heavily on thematisation of malls’s architecture (Irazábal \& Chakravarty, 2007). However, whereas these entertainment-retail centres mostly target a class niche (catering to middle and upper income classes); Plaza Mexico distinctly targets an ethnic niche through economically accessible cultural products.

Criticisms to the negative impacts of the tourist industry on local cultures and people abound. Among them, AlSayyad states, 'culture(s) as embodiments of living traditions are reduced to superficial subjugates of consumerism and lose their active social aspect, political function, and authenticity'. Building on Robinson (2001), he further states that 'tourism establishes a primary unequal relationship [with the locals], since it does not usually take place on the basis of consent and frequently disregards any concern for mutual cultural understanding' (AlSayyad, 2001: 18). However, these negative externalities of international tourism are at least partially overcome in the case of Plaza Mexico, since the local population is the same target clientele as those who work in Plaza Mexico's service activities. This is not to suggest that unequal relations do not exist in Plaza Mexico, since a bartender we interviewed at one of the finer restaurants there earned seven dollars an hour, while wealthy elite politicians from Mexico and Los Angeles are often those being served. Yet, at the same time, Plaza Mexico provides opportunities for employment, leisure, or rest from the long work week to many. One Mexican man who was there in his work clothes at noon said, 'I paint all day and get tired. Here, I can grab a coffee, catch up on local news and just hang around'. 
Hence, at the Plaza, the local and the tourist collide, and their practices there go beyond propitiating consumerism. In effect, they both enhance sales and recreate - and often enhance - social and political dimensions of the community. Since cultural agents and groups and the public at large volunteer to participate in organizing events, and the Public Relations team of Plaza Mexico are fairly responsive to their requests and feedbacks, much of what goes on in the Plaza takes place on the basis of consent with the participants.

The potential for positive, inclusive (both/and) combination of economic and cultural development from tourist enterprises - as is been realised in Plaza Mexico - is acknowledged by Robinson.

Commodification, in itself, need not generate conflict if it carries the consent of the host culture and the latter can reap the benefits of acceptable commercialization. Indeed, while remaining contentious, the presentations of cultural artifacts and cultural history can be identity affirming, cathartic, and liberating for cultures seeking to explain their traditions and values. The key issue relates to the ability of local cultures to decide for themselves what aspects of culture should be displayed and how they should be presented. (Robinson, 2001: 43)

As most of our impromptu surveys with clientele indicated, Plaza Mexico is indeed a place that the locals feel they belong to. It represents them and offers a climate that is identity affirming.

There have been, however, critiques leveraged at mall planners for not including other social groups, especially those from other Latin American nations. This problem, nonetheless, is not insurmountable by capital's ability to increasingly absorb new niche markets (García Canclini, 1999). In an effort to ameliorate the critique, and to include 'all of Latin America', plans have been created for one of the mall's expansions to make a large fountain plaza where maps of Mexico and the United States will be bound together at the centre, surrounded by all Latin American national flags. These representational spaces show the transnational dimension of the Plaza, where Mexico and the United States are at the centre of tourist, migrant, religious, cultural and commercial flows, constituting a bi-national pole of exchange with the rest of Latin America. A different, more subversive interpretation of the map of the United States and Mexico at the centre of the Latin American 
fountain would highlight the Latinisation of the United States, a nation ever more impacted by the presence of Latina/os and their culture. The spatial gesture of the Latin American fountain aims to dispel sentiments of alienation from potentially large clienteles from other Latin American countries in Plaza Mexico and to potentially expand programs and commodities from other Latin American nations. Interestingly, the absence of Canada from this representation of the Americas allows for the fountain to highlight the distinctively 'Latin' branding of the ethnic mall. It also suggests the centrality of the United States as a host land and larger business partner of Mexico (and Plaza Mexico), and the marginal numbers of Canadians that patronise the mall.

\section{Instructing Nationhood and Consumption}

Political and representational struggles of Chicana/os, Mexicans and other groups of Latin American descent in the United States can be broadly characterised as struggles to gain entrance into the nation state with equality before the law. Of course, these political struggles have also been challenged by and opened up to rights of complex subjectivity and intersectional identities (including language, sexual orientation, gender, ethnicity, religiosity, and so on), resulting in people demanding rights to be culturally different and still be equal bearers of civil rights. Holding signs of immigrant presence, Plaza Mexico helps further a historical agenda of inclusion, especially by celebrating and making public and prominent the uniqueness of Mexican culture in the United States. Nonetheless, in the context of a largely asymmetrical, neo-imperial relation between Mexico and the United States, and an neo-conservative immigrant backlash in the latter, Plaza Mexico has a largely hegemonic role reproducing Mexican subjectivity and identity as mostly non-threatening, essentialist and tamed. It thus constitutes a self-orientalist approach. This happens, however, at the heart of the empire (Jacobs, 1996), which, in and of itself, unravels its paradoxical and subversive potential. A key instance of this contradictory representational and political position of Plaza Mexico's 'Mexicanness' shows off its 'all-out-Americanness' in the Thanksgiving celebrations at the mall. The fact that there are Thanksgiving celebrations in Plaza Mexico, thereby excluding indigenous histories and revisionings of what this holiday represents, helps to make the place non-threatening in the 
eyes of nativists when the mall also hosts 5 de Mayo and Grito de Independencia celebrations, both Mexican patriotic celebrations.

Significantly, the homeland that is longed for - like 'the American Dream' immigrants pursue - is not fixed, but rather an elusive and fluxing reality. In effect, Mexico is immersed in a convoluted process of transformation of its national polity. Different projects of nation-building are in conflict and none is likely to get hegemonic control any time soon. The presidential elections celebrated in July 2006 evidenced a country deeply divided along socio-economic and politico-ideological rifts. This is in tandem with a huge social upheaval around immigration reform in the United States that makes undocumented immigrants, the majority of whom are of Mexican origin, the target of repressive policies and practices that treat them as criminal subjects deserving of fines, prison, and/or deportation. The support that the Mexican Embassy and the different regional hometown associations in the Plaza grant to Mexican nationals is a way of both formally and informally exert resistance to the antiimmigrant, xenophobic and racist politics that currently victimise and criminalise Mexicans in the United States.

We have discussed the production of bounded tourism, whereby venture capitalists opportunistically reinvent tradition within a structural context of constrained immigrant mobility. Yet, the last judgment of how well Plaza Mexico represents the nation and the concept of Mexican citizenship lies with the opinions of local tourists, since they, in fact, use and patronise the Plaza in ways that respond to their daily lives. Originally collected in Spanish (Truax, 2005), the following testimonies speak to the sense of cultural belonging the community has developed in Plaza Mexico. Luis García, a business owner of Mexican crafts in the Plaza, particularly of Veracruz, its native state, commented, 'I decided to settle down here because I liked the Plaza, I felt like at home, in the Mexican province.' This notion of 'feeling at home' in fact is a key insight into the sentiment about the place by many that we interviewed. Here is a sample of some response to the question, 'Why do you come here (to Plaza Mexico)?'

I like to come to Lynwood because of Plaza Mexico. I really feel like in Mexico, with the champurrado [beverage] and the elotes [corn]. People can buy things and I like the atmosphere, the people, the fact that they speak in Spanish, ... it makes 
me feel at home. And it's very safe, people are respectful and greet each other. (Olivia Gastélum, visitor)

Coming to Plaza Mexico helps to reinforce the [Mexican] culture in the children. When my girl arrives at the Plaza she comes in the car speaking in English, and when we arrive, she does not realize it, but she begins to speak in Spanish. (Armando Gastélum, visitor)

The Plaza reminds me of the [Mexican] towns, with its kiosk, it seems that one is in Mexico, even with its benches. (Rubén López, visitor)

I liked the place, it is something that is not everywhere that makes you remember where you come from. (Gloria, visitor)

As these quotes show, nostalgia, belonging and culture are all important elements of Plaza Mexico that respond to immigrants' affective needs in a host nation, especially when the possibility of return is severely curtailed.

To disentangle the different processes of nation-building enacted at Plaza Mexico it is useful to refer to Bhabha's (1994) notions of the nation as pedagogy and as performance. The nation emerges as a pedagogical construct in the process of piecing together the official discourses of nation invoked by governments, parties, textbooks, official media, etc. The nation, however, is performed by more informal and ambiguous processes 'in which the identity of the community as a modern nation can be realised only by distinguishing what belongs to the nation for what does not, and by performing this distinction in particular encounters' (Mitchell, 2001: 215). Plaza Mexico is both pedagogical and performative. Its architecture and symbolic landscape teach and reify an official notion of nationhood. In addition, both the everyday market performances and the extraordinary cultural performances enacted in the Plaza reinforce its pedagogical intents. In this case, the nation as performance in Plaza Mexico does not 'bring into view the forms of difficulty, uncertainty, violence and subversion that the making of the nation can involve' (Mitchell, 2005: 215), but instead veils them through the reassertion of a seemingly uniform and stable collective identity. Nonetheless, even then there are openings for subversions, as Mitchell has suggested: '[n]ation-making is a performance that remains open to improvisation and restaging. Such restagings are not 
the subversive acts of outsiders, but the imaginative response of those in whose lives the nation is performed' (2001: 221-222).

In the global era, new forms of cultural nationalisms arise. Buell has termed this phenomenon 'nationalist postnationalism' (Buell, 1998). More specifically, we call this process in Plaza Mexico nationalist transnationalism. The Plaza embodies the paradox of drawing from and redefining a transnational 'space of national imagining' (Crysler, 2006: 21). Performing upon a disjuncture of memory and location, the Plaza is a teaching tool for the specific constructed model of nationalist-transnational Mexican identity it offers. The generalist nature of the Plaza narrative helps fold the diversity of Mexicans and Mexicanness into a single, coherent Mexican story that partake of one history and one set of traditions, a kind of fantasy nationalisttransnational community. Spectacular representations of certain Mexicanness in Plaza Mexico becomes a vehicle for reifying the nation state as a conflict free, unifying notion for Mexicans and Latina/os of Mexican descent away from the homeland. The significance and impact of such project is magnified when the hosting nation is the United States, which is immersed in a climate of increasing racial tensions and anti-immigration sentiments. Thus, Plaza Mexico is also spectacularly representing 'proper' Mexican neighbourhood to US citizens through aesthetically-approvable ethnic architecture and artistic expressions. Such cultural expressions, when contained and managed within a corporate mall, can be controlled in a manner that is non-threatening to the dominant Anglo culture. Instead, they can be exoticized for the enjoyable consumption of US tourists and naturalised for the reproduction of 'good' Mexican citizenship in Mexican performers. Crafting an idealised model of the Mexican nation based on selected and fragmented representations of its past erases politically charged histories and prevents competing interpretative histories and models of Mexicanness.

Plaza Mexico is a model by which a corporation has 'set the stage' to become a vehicle for the symbolic performativity of nostalgias, regionalisms, and (trans)nationalisms as indexes of diasporic loyalties and traditions linked to a mythic homeland - in this case, as indexes of Mexicanness linked to idealised notions of Mexico. The practices of shopping, strolling around, and participating in ethnic 
cultural events within an enframing, make-believe architecture operate together to naturalise a pre-formulated and formulaic model of Mexicanness.

Similar to technologies and narratives of nationhood deployed by national museums (Crysler, 2006) and miniature parks (Türeli, 2006), Plaza Mexico is an instrument in the reconstruction of conceptions of nationhood. As a matter of fact, Plaza representatives offer guided tours in which they explain to visitors the significance of all the pieces in display (façades, statues, etc.). The mall is also often used by teachers and parents showing their students and children different aspects of the history and culture of Mexico. As distinct from museums or miniature parks, however, Plaza Mexico is a shopping centre owned and run by private entrepreneurs, rather than a nation state project (even if run by private hands). Miniature parks and certain museums are showcases in which contemporary national identities can be projected for international audiences, whereas Plaza Mexico projects a national identity of a foreign country for a targeted diaspora in the US Museums and miniature parks usually target a broad audience of nationals and internationals alike, attempting to portray a country's cultural wealth as an asset for its competitiveness in the global marketplace. Plaza Mexico, instead, targets a local diasporic population and is not as interest in portraying competitiveness in the global marketplace as it is in making an economically tangible and immediate profit locally. Museums and miniature parks are more focused on technologies of nationhood and citizenship, favouring pedagogy over consumption; whereas Plaza Mexico focuses on economies of desire and commodification of culture, with pedagogies of nationhood at the service of consumption. There is, however, an increasingly blurred line between these models. As Türeli explains, projects 'offered to global capital or leisure environments ... are characteristic of globalisation. [They] are domestic translations of global types; [which] entail the rerouting of public sources into private or privatised services’ (2006: 60).

The creation of national identity from the top down has for long been an important project of nation states, and many have resorted to urban building campaigns to do that (AlSayyad, 2001). In this case, however, Mexican national identity is recreated by a private 
corporation run by Korean entrepreneurs in a foreign country basically because it is good for sales. The side effects of this move, however, is a place that can enhance cultural capital and community building opportunities. Fortunately in the case of Plaza Mexico, these capabilities have been embraced both by the owners and managers of the mall and by the community. This case thus provides a perfectible partnership model to emulate for entrepreneurs, city officials, and community leaders interested in advancing economic and community development objectives in tandem through crosssectoral collaboration among the public, private, and non-profit arenas.

\section{Mediation and Performativity in Plaza Mexico}

Although conceived as an urban island design-wise, separated from the street grid of Lynwood by a parking lot, Plaza Mexico is not separated from the surrounding everyday reality and history. However, contrasting differences between Lynwood and Plaza Mexico are worth noting. The conflict free, decontextualised portrayal of Mexico in Plaza Mexico collides with local socioeconomic issues and lifestyles of its surrounding community. Latino urbanism in Lynwood, an expression of the tensions 'between socially deforming (barrioizing) and culturally affirming (barriological) spatial practices - which together produce the form and meaning of the barrio' (Villa, 2000: xx) - recreates Mexican and Chicana/o culture in the city in a different manner than does the Plaza. Economic conditions and urban policies (such as zoning) effect the expression of cultural preferences in the everyday built environment inhabited by Latina/os in Lynwood and Southern California. These questions are extensively explored elsewhere (Gómez-Barris \& Irazábal, 2006a; Irazábal \& Gómez-Barris, 2005; see also Méndez, 2005). Here, however, we want to highlight the difference between the selective focus on Mexican nationalistic motives of pride to be memorialised and celebrated in Plaza Mexico (through architecture, statues, cultural events, etc.) and the everyday, making-life expressions of urban inhabiting at the Lynwood barrio as a result of economic constraints, urban policies and cultural preferences. The reinvention of Mexicanness at the Southern California barrio is worlds apart in both material and imaginary ways from Plaza Mexico's: whereas Latinos modestly adjust their 
domestic and public spaces around the city to ease their ordinary, everyday lives; the reinvention of Mexicanness at the Plaza turns it into an spectacular escapist space 'designed to produce "liminal moments" that lift the tourist above ordinary, everyday experience' (Fainstein \& Judd, 1999b: 10).

Touring Plaza Mexico offers 'elabourate emotional landscapes' (Crysler, 2006: 31) for reconstituting identities through simulating the experience of idealised national history in a transnational, reterritorialised location. This idealised space of national history create economies of desire that both create the conditions for and reproduce the ability to consume material commodities, all while subtly disciplining subjects into alignment with an objectified history. What is formed is not an ahistorical collective identity, but instead one that is hyper-historical - composed of superposed fragments of non-chronological, composite histories that appear to hold together but upon close inspection are a kind of mirage of national history. As a mediator between empire and subject, Plaza Mexico is constituted as a place where Mexican immigrants visit their object of nostalgia, desire and fantasy (Mexico abroad, where Mexico once was), and where a seemingly apolitical (i.e. postimperial, 'pax-americana') media text (based on architecture and events) tries to freeze subjects into pre-established cultural hierarchies. The main managers of these processes of ordering and control are not nation states but venture capitalists working to construct a national image through grand narratives and technologies of nationhood. Private developers and commercial entrepreneurs profiteer by commodifying heritage imaginaries. Ultimately, they sustain this transnational tourist place through the paradoxical special effects of recreating tradition and producing a market for modern locally-bound tourists.

But not only is the phenomenon of ascribing meaning to Plaza Mexico's symbols and events the prerogative of the mall's owners, designers and managers. Meanings at the Plaza, as in any other social space, are socially constructed (Gottdiener et al., 1999). Visitors have different motivations, and more importantly, differently reactions and responses to their experiences in the place. Unlike Crysler's reflection on museums, which present 'an image of nation in which collective agency is confined in the past, where it 
can be remembered, curated, and reflected upon - but not mobilised in the present' and 'represent the nation as a mute container that is simply there, outside culture and history' (2006: 19-30), we found that the Plaza poses 'productive inscriptions' (Huyssen, 2003), whereby the meanings and narratives associated with symbols and events in the Plaza are transformed by visitors. In the process, reinscriptions reshape public memories (Gómez-Barris, 2008). Examples abound, from the appropriation of the place for the reenactment of traditions (e.g. folk dances) to the more politically subversive ones, such as the gathering of pro-immigrant rallies. Furthermore, the symbols at the Plaza have begun to develop their own mythologies, such as the man who claimed a Virgin of Guadalupe miracle when he won a Ferrari car in a raffle, because he had been praying to the image of the Virgin for it before his winning number was drawn.

Plaza Mexico has also been appropriated by the community as a place from which to launch translocal subject formations. This is true both for people of Mexican descent encountering each other and for visitors of other cultural backgrounds allowing themselves to encounter and become the other. In the multicultural region of Southern California, Plaza Mexico constitutes a place of 'sensual alterity’ (Edensor, 2006: 45), offering non-Latino visitors the 'opportunities for opening out to otherness and decentreing the self ... through experiencing the affect engendered by the touch, smell, and sound of other-ness'. Plaza Mexico is also the first source of economic revenue for the city of Lynwood (Truax, 2005). Apart from the monetary benefits, the Plaza has become a cultural, artistic, and even a political hub for the Mexican community in the region. The Mexican states of Puebla and Durango have established their Hometown Associations there, and Mexican representatives that visit Southern California officially visit the Plaza, some to donate symbolic monuments for it. Interestingly, a foundation has been created as the keeper of such monuments. The representations of cultural artifacts and history have helped participants explain their traditions and values, not so much to 'others' but to themselves and their children, perpetuating them in an ongoing cycle of reinvention (Hobsbawn, 1983). 
At the end, the most critical question may be, to what extent Plaza Mexico facilitates for its visitors processes of 'performative reflexivity', defined by Turner as a condition by which people 'turn, bend, or reflect back upon themselves, upon their relations, actions, symbols, meanings, codes, statuses, social structures, ethical and legal rules, and other socio-cultural components which make up their public selves'? (Turner, 1986: 24; cited in Minca \& Oakes, 2006: 9). The de/recontextualisation of meaningful symbols of the Mexican past in Plaza Mexico produces an illusionary field on which both to construct a collective identity around a shared notion of Mexicanness and to imagine and mobilise towards a different common future. The latter opens up venues for agency and political engagement based on ethnic solidarity. Such challenge has open possibilities in Plaza Mexico and the type of 'diasporic touristed ethnoscape’ it represents.

\section{Conclusion}

Placita Olvera (Olvera Street) provides a critical historical precursor in the City of Angels for how nostalgia, tourism, and Latina/o (Mexicana/o) subjectivity are bound up with questions of nostalgia, homeland and belonging. At the same time, Plaza Mexico represents a critical departure from places like Olvera Street and Chinatown in Los Angeles, especially in terms of the specialisation of its planning, the heightened reification of foreign national symbols and the intense cultivation of a specifically local market clientele whose sense of contemporary homeland, culture and nation are all on 'postmodern' offer at the Plaza. We have analysed how structural shifts in immigrant policies, a generalised culture of fear and immigrant backlash, and an increasingly militarised border produce conditions of staying put, a phenomenon under-explored in comparison to the conventional transnational circuits of movement across borders widely recognised in the literature. An ever-expanding capitalist economy picks up on mobility constraints to produce an image of homeland that reifies 'the colonial present', even while it makes room for regional and distinctive Mexican culture and national iconography. While claims to authenticity abound at Plaza Mexico, the place has a hold over hearts, minds and memories, not only because of its elicitation of feeling of being 'there' rather than 'here' or its ethnic commercial offerings (indeed ethnic commerce has 
always been at the centre of these communities). More importantly, as we discussed, Plaza Mexico tries to reimagine the nation for immigrants who are structurally but not imaginatively constrained and look for ethnoscapes of escape. Plaza Mexico, as a mall and multi-layered architectural project, and even projected as a cultural centre of ever greater possibilities, offers a privatised 'public' space that both controls and releases the promises of future forms of social being and belonging in the urban landscape.

\section{Acknowledgements}

We appreciate the support of the Urban Initiative and the Center for Religious and Civic Culture of the University of Southern California for this research, and the help of PhD students Luis Carlos Rodríguez, Micaela Smith, and Ramzi Farhat.

\section{Correspondence}

Any correspondence should be directed to Assistant Professor Clara Irázabal, School of Public Policy, Planning and Development, University of Southern California, 650 Childs Way, RGL 226, Los Angeles, CA 90089-0626, USA (irazabal @usc.edu).

\section{Notes}

1. The video of Plaza Mexico shown in its website is done to the instrumental strains of Alavéz's popular song. This Mexican immigrant lament was made famous Cuco Sánchez (1921-2000).

2. Robert Courtney Smith (2006: 26-27) has found that niche work for Mexicans in the service sector in the US expanded in the 1990s, even while there are important pathways of mobility for women of Mexican heritage in secretarial and retail work.

3. Ethnic enclaves are neighbourhoods in which a certain ethnic group prevails. Many of these constitute diasporic neighbourhoods, communities formed by people from a particular country or region of the world who migrate to another country. In their host new country, they usually develop bounds of ethnic solidarity that both 
help them adjust to their new land and preserve certain traditions from their homeland.

4. Plaza Mexico receives visitors from the entire Southern California region, particularly from the neighbouring Gateway Cities region composed of more than 20 cities. However, taking into consideration the demographics of Lynwood, the following comparison with United States data reveals the economic disadvantage of the city's population: the median household income in 1999 (dollars) was 35,888 for Lynwood, and 41,994 for the United States; median family income in 1999 (dollars) was 35,808 for Lynwood, and 50,046 for the United States; per capita income in 1999 (dollars) was 9542 for Lynwood, and 21,587 for the United States; families below poverty level were 2734 or $21.0 \%$ for Lynwood, and $9.2 \%$ for the United States; and individuals below poverty level were 15,850 or 23.5\% for Lynwood, and 12.4\% for the US Lynwood's average household size was 4.70 and the United States 2.59; and the city's average family size was 4.76 and the United States 3.14 (US Census Bureau, 2000).

5. The Treaty's provisions called for Mexico to cede this territory in exchange for fifteen million dollars in compensation for war related damage to Mexican property.

6. This is a risky business. Migrant groups estimate 500 people died trying to cross the US-Mexico border in 2005. The Border Patrol reported 473 deaths as of 30th September.

7. In Alienhood, Katarzyna Marciniak (2006) explores the semantic duality of 'alien' in the United States, suggesting both 'foreigner' and 'extraterrestrial creature'. She theorises multicultural experiences of liminal characters that belong in the interstices between nations. In relevance to our arguments about Plaza Mexico, Marciniak's work problematises the meanings of the celebrated notion of transnationalism, showing how transnationality is, for many dislocated people, an unattainable privilege.

8. This discussion of ethnoscape draws on the work of Irazábal and Punja (2007). 


\section{References}

Abrahamson, M. (1996) Urban Enclaves: Identity and Place in America. New York: St. Martin’s Press.

Abrahamson, M. (2005) Urban Enclaves: Identity and Place in the World. New York: Worth Publishers.

Aguilar, C. (2006) Plaza Mexico’s Director of Public Relations and President of Casa Guanajuato. Interviewed by the authors, May 26, Plaza Mexico, Lynwood.

AlSayyad, N. (2001) Global norms and urban forms in the age of tourism: Manufacturing heritage, consuming tradition. In $\mathrm{N}$. AlSayyad (ed.) Consuming Tradition, Manufacturing Heritage: Global Norms and Urban Forms in the Age of Tourism. London: Routledge.

Appadurai, A. (1995) Disjuncture and difference in the global cultural economy. In M. Featherstone (ed.) Nationalism, Globalization and Modernity. London: Sage.

Appadurai, A. (1996) Modernity at Large: Cultural Dimensions of Globalization. University of Minnesota Press; Minneapolis.

Banerjee, T. (2001) The future of public space: Beyond invented streets and reinvented places. APA Journal 67, 9-24.

Bhabha, H. (1994) DissemiNation: Time, narrative, and the margins of the modern nation. In The Location of Culture. London and New York: Routledge.

Brady, M.P. (2002) Extinct Lands, Temporal Geographies: Chicana Literature and the Urgency of Space. Durham and London: Duke University Press.

Buell, F. (1998) Nationalism postnationalism: Globalist discourse in contemporary American culture. American Quarterly 50b (3); 551. 
Camarillo, A. Not White, Not Black: Mexicans and Racial/Ethnic Borderlands in American Cities. Oxford University Press, in press.

Cartier, C. (2005) Introduction: Touristed landscapes/seductions of place. In C. Cartier and A. Lew (eds) Seductions of Place: Geographical Perspectives on Globalization and Touristed Landscapes. Oxon: Routledge.

Cartier, C. and Lew, A. (eds) (2005) Seductions of Place: Geographical Perspectives on Globalization and Touristed Landscapes. Oxon: Routledge.

Cohen, A.P. (1985) The Symbolic Construction of Community. Chichester: Ellis Horwood Ltd.

Crang, M. (2006) Circulation and emplacement: The hollowed-out performance of tourism. In C. Minca and T. Oakes (eds) Travels in Paradox: Remapping Tourism. Lanham, MD: Rowman \& Littlefield Publishers, Inc.

Crick, M. (1989) Representations of international tourism in the social sciences. Annual Review of Anthropology 18, 307-344.

Crouch, D. (2005) Flirting with space: Tourism geographies as sensuous/expressive practice. In C. Cartier and A. Lew (eds) Seductions of Place: Geographical Perspectives on Globalization and Touristed Landscapes. Oxon: Routledge.

Crysler, G. (2006) Violence and empathy: National museums and the spectacle of society. Traditional Dwellings and Settlements Review XVII (11), 19-38.

Culler, J. (1981) Semiotics of tourism. American Journal of Semiotics 1 (1-2), 127-140.

Deverell, W. (2004) Whitewashed Adobe: The Rise of Los Angeles and the Remaking of its Mexican Past. Berkeley and Los Angeles: University of California Press. 
Dirlik, A. (1994) After the Revolution: Waking to Global Capitalism. Hanover, CT: Wesleyan University Press.

Edensor, T. (2006) Sensing tourist spaces. In C. Minca and T. Oakes (eds) Travels in Paradox: Remapping Tourism. Lanham, MD: Rowman \& Littlefield Publishers, Inc.

Estrada, W.D. (1999) 'Los Angeles' Old Plaza and Olvera Street: Imagined and contested space. Western Folklore 58 (Winter), 107129.

Fainstein, S. and Judd, D. (1999a) Cities as places to play. In D. Judd and S. Fainstein (eds) The Tourist City. New Haven and London: Yale University Press.

Fainstein, S. and Judd, D. (1999b) Global forces, local strategies, and urban tourism. In D. Judd and S. Fainstein (eds) The Tourist City. New Haven and London: Yale University Press.

García Canclini, N. (1999) Hybrid Cultures: Strategies for Entering and Leaving Modernity. Minneapolis: University of Minnesota.

Gómez-Barris, M. (2008) Where Memory Dwells. Berkeley: University of California Press, Forthcoming.

Gómez-Barris, M. and Irazábal, C. (2006a) Latino New Urbanism in Los Angeles. Paper presented at the LASA Conference. San Juan, Puerto Rico, March.

Gómez-Barris, M. and Irazábal, C. (2006b) Plaza Mexico and the mobilization of immigrant religiosity in Lynwood. Paper presented at the IASTE Conference. Bangkok, Thailand, December.

Gottdiener, M. (1995) Postmodern Semiotics: Material Culture and the Forms of Postmodern Life. Oxford, Cambridge, USA: Blackwell.

Gottdiener, M. (ed.) (2000) New Forms of Consumption: Consumers, Culture, and Commodification. Lanham, MD: Rowman \& Littlefield Publishers. 
Gottdiener, M. (2001) The Theming of America: Dreams, Media Fantasies, and Themed Environments (2nd edn). Boulder, CO: Westview Press.

Gottdiener, M., Collins, C. and Dickens, D. (1999) Las Vegas: The Social Production of an All-American City. Malden, MA: Blackwell Publishing.

Gregory, D. (2001) Colonial nostalgia and cultures of travel: Spaces of constructed visibility in Egypt. In N. AlSayyad (ed.) Consuming Tradition, Manufacturing Heritage: Global Norms and Urban Forms in the Age of Tourism. London: Routledge.

Hise, G. and Deverell, W. (eds) (2005) Land of Sunshine: An Environmental History of Metropolitan Los Angeles. Pittsburgh: University of Pittsburgh Press.

Hobsbawn, E. 1983. Introduction: Inventing traditions. In E. Hobsbawn and R. Ranger (eds) The invention of tradition. London: Cambridge University Press.

Hobsbawn, E. and Ranger, R. (eds) (1983) The Invention of Tradition. London: Cambridge University Press.

Huntington, S. The Hispanic Challenge. Foreign Policy, March/April 2004a.

Huntington, S. (2004) Who Are We? The Challenges to America's National Identity. New York: Simon \& Schuster.

Huyssen, A. (2003) Present pasts: Urban Palimpsests and the Politics of Memory. Palo Alto: Stanford University Press.

Irazábal, C. and Chakravarti, S. (2007) Entertainment-retail centres in Hong Kong and Los Angeles. International Planning Studies 12 (3), 237-267.

Irazábal, C. (2004) Architecture and the production of postcard images: Invocations of tradition vs. critical transnationalism in 
curitiba. In N. AlSayyad (ed.) The End of Tradition? London:

Routledge.

Irazábal, C. (2005) City Making and Urban Governance in the Americas: Curitiba and Portland. London: Ashgate.

Irazábal, C. and Farhat, R. (2008) Latino communities in the United States: Place-making in the pre-World War II, postwar, and contemporary city.

Irazábal, C. (2007) Kitsch is dead, long live kitsch: The production of hyperkitsch in Las Vegas. Journal of Architectural and Planning Research 24 (3), 199-223.

Irazábal, C. and Punja, A. (2007) South Central Farm in Los Angeles. Poster presented at the Annual Conference of the Association of Collegiate Schools of Planning, Milwaukee, October.

Irazábal, C. and Gómez-Barris, M. (2005) Latino new urbanism : Reformulations of urban practices and living preferences in Los Angeles. Paper presented at the Association of Collegiate Schools of Planning (ACSP) 2005 National Conference, 'Beyond the City Beautiful’. Kansas, Missouri, 27-30 October.

Jacobs, J.M. (1996) Edge of Empire: Postcolonialism and the City. London; New York: Routledge.

Judd, D. and Fainstein, S. (eds) (1999) The Tourist City. New Haven and London: Yale University Press.

King, A. (ed.) (1991) Culture, Globalisation, and the World-System. London: MacMillan.

Latour, B. (2005) Reassembling the Social: An Introduction to Actor-Network-Theory. Oxford: Oxford University Press.

Lew, A. and Cartier, C. (2005) Conclusion: Centering tourism geography. In C. Cartier and A.A. Lew (eds) Seductions of Place: Geographical Perspectives on Globalization and Touristed Landscapes. Oxon: Routledge. 
Lew, A. and Wong, A. (2005) Existential tourism and the homeland: The overseas Chinese experience. In C. Cartier and A.A. Lew (eds) Seductions of Place: Geographical Perspectives on Globalization and Touristed Landscapes. Oxon: Routledge.

Light, I. and Gold, S.J. (2000) Ethnic Economies. San Diego: Academic Press.

Malpas, J.E. (1999) Place and Experiecnce: A Philosophical Topography. Cambridge: Cambridge University Press.

Marciniak, K. (2006) Alienhood: Citizenship, Exile, And The Logic Of Difference. MN: University of Minnesota Press.

Massey, D. (1993) Power geometry and a progressive sense of place. In J. Bird, B. Curtis, T. Putnam, G. Robertson and L. Tickner (eds) Mapping the Futures: Local Cultures, Global Change. New York: Routledge.

McCain, J. (2004). Letter from Sen. John McCain (R-AZ, a state with extremely high illegal numbers) to citizens. 10 February, 2004.

Méndez, M.A. (2005) Latino new urbanism: Building on cultural preferences. Opolis, An International Journal of Suburban and Metropolitan Studies 1 (1), Winter.

Minca, C. Reinventing the "square": Postcolonial geographies and tourist narratives in Jamaa el Fna, Marrakech. In C. Minca and T. Oakes (eds) Travels in Paradox: Remapping Tourism. Lanham, MD: Rowman \& Littlefield Publishers, Inc.

Minca, C. (2005) Bellagio and beyond. In C. Cartier and A.A. Lew (eds) Seductions of Place: Geographical Perspectives on Globalization and Touristed Landscapes. Oxon: Routledge.

Minca, C. and Oakes, T. (eds) (2006) Travels in Paradox: Remapping Tourism. Lanham, MD: Rowman \& Littlefield Publishers, Inc. 
Minca, C. and Oakes, T. (2006) Introduction: Traveling paradoxes. In C. Minca and T. Oakes (eds) Travels in Paradox: Remapping Tourism. Lanham, MD: Rowman \& Littlefield Publishers, Inc.

Mitchell, T. (2001) Making the nation: The politics of heritage in Egypt. In N. AlSayyad (ed.) Consuming Tradition, Manufacturing Heritage: Global Norms and Urban Forms in the Age of Tourism. London: Routledge.

Myers, D. (2001) Demographic futures and a guide to planning. California's Latinos and the compact city, APA Journal 67 (4), 383397.

Neumann, M. (1992) The trail through experience: Finding self in the recollection of travel. In C. Ellis and M. Flaherty (eds) Investigating Subjectivity: Research on Lived Experience. London: Sage.

Oakes, T. (2005) Tourism and the modern subject: Placing the encounter between tourism and other. In C. Cartier and A.A. Lew (eds) Seductions of Place: Geographical Perspectives on Globalization and Touristed Landscapes. Oxon: Routledge.

Oakes, T. (2006) Get real! On being yourself and being a tourist. In C. Minca and T. Oakes (eds) Travels in Paradox: Remapping Tourism. Lanham, MD: Rowman \& Littlefield Publishers, Inc.

Ohon, S. (2001) Latinos in Ethnic Enclaves: Immigrant Workers and the Competition for Jobs. New York: Garland.

Peña, D. (2003a) Identity, place, and communities of resistance. In J. Agyeman et al. (eds) Just Sustainabilities: Development in an Unequal World. London: Earthscan.

Peña, D. (2003b) The scope of Latino/a environmental studies. Latino Studies 1, 47-78.

Pulido, L. (2006) Black, Brown, Yellow and Left: Radical Activism in Los Angeles. Berkeley and Los Angeles: University of Califronia Press. 
Robertson, R. (1991) Social theory, cultural relativity, and the problem of globality. In A. King (ed.) Culture, Globalisation, and the World-System. London: MacMillan.

Robinson, M. (2001) Tourism Encounters: Inter- and intra-cultural conflicts and the world's largest industry. In N. AlSayyad (ed.) Consuming Tradition, Manufacturing Heritage: Global Norms and Urban Forms in the Age of Tourism. London: Routledge.

Rojek, C. (1997) Indexing, dragging and the social construction of tourist sights. In C. Rojek and Urry, J. (eds) Touring Cultures: Transformations of Travel and Theory. London and New York: Routledge.

Romo, R. (1983) History of a Barrio: East Los Angeles. Augustin: University of Texas Press.

Rushdie, S. (1991). Imaginary Homelands. London: Granta.

Saarinen, J. (2006) Tourist Destinations and Attractions: Interpretations of the Spatiality of Tourist Motives. On WWW at http://www.geo.ruc.dk/NST/NST26/Saarinen26.html. Accessed 02.08.2006.

Sanchez, G. (1993) Becoming Mexican American: Ethnicity, Culture and Identity in Chicano Los Angeles, 1900-1945. Oxford: Oxford University Press.

Smith, R. (2006) Mexican New York: Transnational Lives of New Immigrants. Berkeley; University of California Press.

Truax, E. (2005) Lynwood: Nuevo corazón de México. La Opinión, 19 de diciembre de 2005. On WWW at http://www.laopinion.com/supp75/?rkey=00060122165148291908.

Türeli, I. (2006) Modeling citizenship in Turkey’s miniature park. Traditional Dwellings and Settlements Review XVII (11), 55-69. 
Turner, L. and Ash, J. (1975) The Golden Hordes. London:

Constable.

Turner, V. (1986) The Anthropology of Performance. New York:

Performing Arts Journal Publications.

US Census Bureau. (2000) American Factfinder. on WWW at http://factfinder.census.gov/. Accessed 1.8.06.

Upton, D. (2001) “Authentic” anxieties. In N. AlSayyad (ed.)

Consuming Tradition, Manufacturing Heritage: Global Norms and Urban Forms in the Age of Tourism. London: Routledge.

Urry, J. (2002) The Tourist Gaze. (2nd edn). London: Sage.

Urry, J. (2006) Preface: Places and performances. In C. Minca and T. Oakes (eds) Travels in Paradox: Remapping Tourism. Lanham, MD: Rowman \& Littlefield Publishers, Inc.

Veijola, S. (2006) Heimat tourism in the countryside: Paradoxical sojourns to self and place. In C. Minca and T. Oakes (eds) Travels in Paradox: Remapping Tourism. Lanham, MD: Rowman \& Littlefield Publishers, Inc.

Villa, R. (2000) Barrio-Logos-Space and Place in Urban Chicano Literature and Culture. Austin, TX: University of Texas.

Waldinger, R. (1986) Through the Eye of the Needle: Immigrants and Enterprise in New York’s Garment Trades. New York: New York University Press.

Zhou, M. (1992) Chinatown: The Socioeconomic Potential of an Urban Enclave. Philadelphia, PA: Temple University Press.

Zukin, S. (1991) Landscapes of Power: From Detroit to Disney World. Berkeley: University of California Press. 